\title{
Dynamics of Calcium-Induced Insulin Release
}

\author{
G. Devis, G. Somers, and W. J. Malaisse \\ Laboratories of Experimental Medicine, Brussels University Schools of Medicine, Brussels, Belgium
}

Summary. Extracellular $\mathrm{Ca}^{2+}$, at concentrations exceeding $10 \mathrm{mmol} / \mathrm{l}$, causes a dose-related stimulation of insulin release. The dynamics of $\mathrm{Ca}^{2+}$-induced insulin release are characterized by a quick onset, a progressive build-up and a later return towards basal secretory rate. The release of insulin evoked by $\mathrm{Ca}^{2+}$ is inhibited in the presence of either $\mathrm{Mg}^{2+}(10 \mathrm{mmol} / \mathrm{l})$ or the organic $\mathrm{Ca}^{2+}$-antagonist verapamil $(81 \mu \mathrm{mol} / 1)$, both of which are known to inhibit $\mathrm{Ca}^{2+}$ entry in the B-cell. Glucose and theophylline, which are thought to affect the net uptake or intracellular distribution of $\mathrm{Ca}^{2+}$ in the $\mathrm{B}$-cell, both enhance $\mathrm{Ca}^{2+}$-induced insulin release. As little as $2.7 \mathrm{mmol} / 1$ glucose is sufficient to augment $\mathrm{Ca}^{2+}$ induced insulin secretion. Exposure of the pancreas to somatostatin significantly retards the secretory response to $\mathrm{Ca}^{2+}$. Cytochalasin $\mathrm{B}$ potentiates the insulin release evoked by $\mathrm{Ca}^{2+}(12 \mathrm{mmol} / \mathrm{l})$ and lowers the threshold concentration of $\mathrm{Ca}^{2+}$ required to stimulate secretion. These data suggest that high extracellular $\mathrm{Ca}^{2+}$ concentrations may sufficiently increase the amount of $\mathrm{Ca}^{2+}$ accumulated in the B-cell to eventually trigger insulin release. Agents known to cause a remodelling of $\mathrm{Ca}^{2+}$ fluxes across membrane systems in the $\mathrm{B}$-cell interfere with $\mathrm{Ca}^{2+}$ induced insulin release, a process also dependent on the integrity of the cytochalasin B-sensitive microfilamentous effector system.

Key words: $\mathrm{Ca}^{2+}$, insulin release, $\mathrm{Mg}^{2+}$, verapamil, somatostatin, cytochalasin $\mathrm{B}$, glucose, theophylline, perfused pancreas.

Intracellular $\mathrm{Ca}^{2+}$ plays an essential role in the process of insulin release [1]. It is generally considered that $\mathrm{Ca}^{2+}$ acts as a trigger for the machinery controlling the exocytosis of secretory granules, whatever agent is used to stimulate insulin release [2]. This concept is supported by the recent finding that
$\mathrm{Ca}^{2+}$ itself is able to promote insulin release $[3,4]$. The secretory response evoked by high extracellular $\mathrm{Ca}^{2+}$ concentrations is influenced by agents known to inferfere with $\mathrm{Ca}^{2+}$ fluxes into or within the B-cell, such as verapamil, L-epinephrine and methylxanthines $[3,4]$.

The present experiments were designed to characterize the dynamics and mechanism of $\mathrm{Ca}^{2+}$-induced insulin release.

\section{Material and Methods}

Pancreases were removed from fully fed, male albino rats (approximately $250-300 \mathrm{~g}$ body weight) and placed in an open circuit extracorporeal perfusion unit, as described in detail elsewhere [5]. The perfusate consisted of a Hepes buffer $(25 \mathrm{mmol} / \mathrm{l} ; \mathrm{pH}$ 7.4) with the following ionic composition: $\mathrm{Na}^{+} 130$, $\mathrm{K}^{+} 5, \mathrm{Mg}^{2+} 1$ and $\mathrm{Cl}^{-} 122 \mathrm{mmol} / \mathrm{l}$. The use of a Hepes- as distinct from bicarbonate-buffered medium allowed the use of $\mathrm{Ca}^{2+}$ in high concentrations without causing precipitation of $\mathrm{Ca}^{2+}$ salts. In view of the results reported by Hellmann [4], no compensation for the changes in osmotic pressure were made, the osmolarity varying between $313\left(\mathrm{Ca}^{2+} 10\right.$ $\mathrm{mmol} / \mathrm{l})$ and $337\left(\mathrm{Ca}^{2+} 18 \mathrm{mmol} / \mathrm{l}\right) \mathrm{mosmol} / \mathrm{l}$. The perfusate also contained albumin $(5 \mathrm{mg} / \mathrm{ml}$; Fraction V; Sigma Chemicals Co., St. Louis, Mo), dextran (40 mg/ml; T70; Pharmacia Fine Chemicals, Uppsala, Sweden) and as required glucose, theophylline, verapamil (Knoll A. G., Ludwigshafen, Germany) somatostatin (G.I.F.; linear synthetic lyophilized; I. F. Serono, Rome, Italy) and cytochalasin B (Aldrich Chemical Co., Milwaukee, Wisconsin), which was dissolved in dimethylsulphoxide (final concentration of the solvent: $0.1 \%, V / V)$. The immunoassay method for insulin is detailed elsewhere [5]. The rates of insulin secretion are expressed as $\mu \mathrm{U} / \mathrm{min}$ per pancreas. 

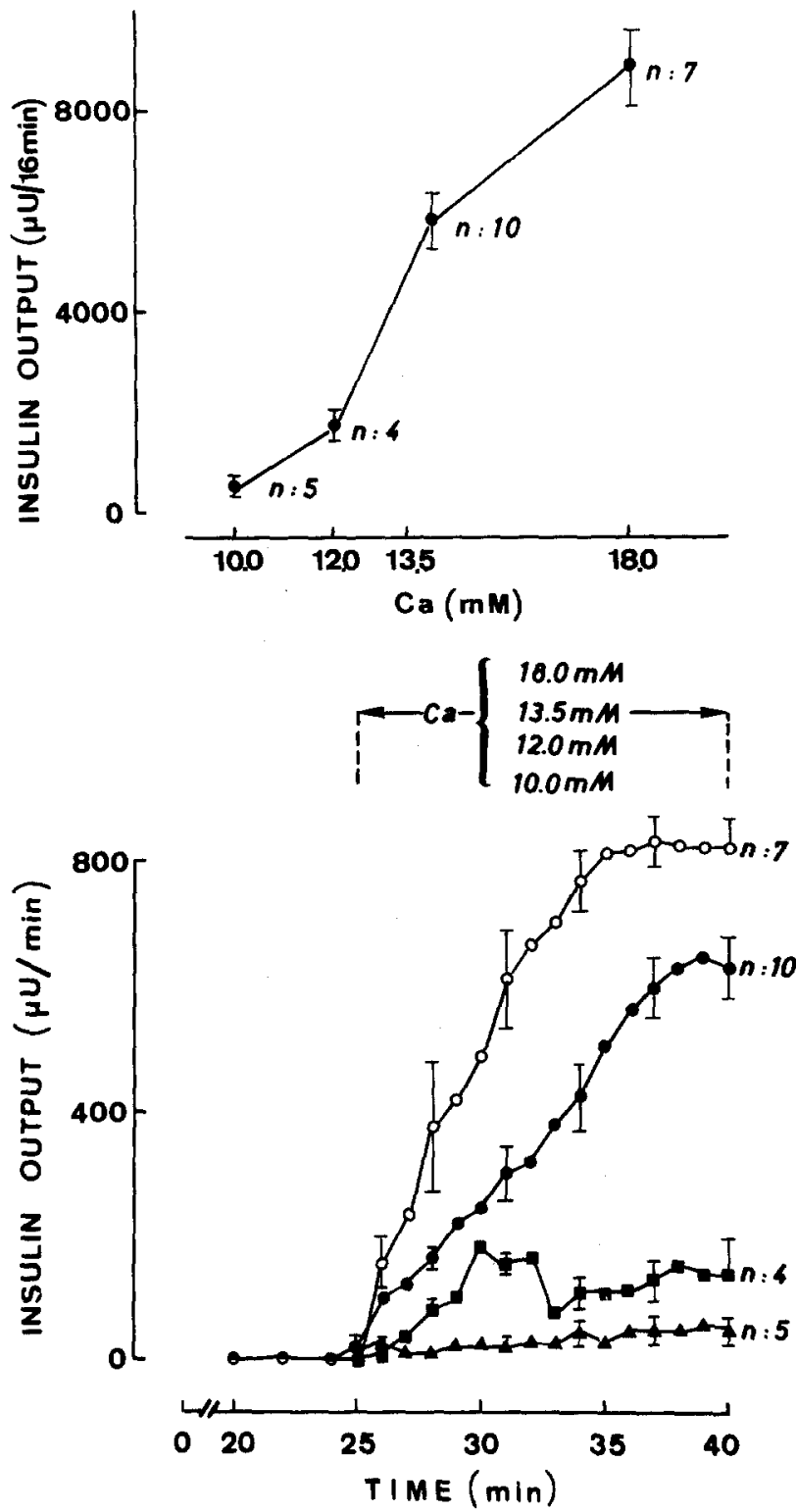

Fig. 1. Dose-action relationship for $\mathrm{Ca}^{2+}$-induced insulin release in the isolated perfused rat pancreas. Lower panel: insulin release by the isolated perfused rat pancreas exposed for $24 \mathrm{~min}$ to a $\mathrm{Ca}^{2+}$-free medium and from the 25 th to the 40 th min to media containing increasing concentrations of $\mathrm{Ca}^{2+}(10 \mathrm{mmol} / \mathrm{l}$ : closed triangles; $12 \mathrm{mmol} / \mathrm{l}$ : closed squares; $13.5 \mathrm{mmol} / \mathrm{l}$ : closed circles; and $18 \mathrm{mmol} / \mathrm{l}$ : open circles). Upper panel: insulin release is expressed as the integrated output over the $16 \mathrm{~min}$ of perfusion following the introduction of extracellular $\mathrm{Ca}^{2+}$. Mean values $( \pm$ SEM) are shown together with the number of individual experiments ( $\mathrm{n}$ )

\section{Results}

Dose-Action Relationship for $\mathrm{Ca}^{2+}$-Induced Insulin Release

After perfusion for 25 minutes with a solution free of $\mathrm{Ca}^{2+}$, the pancreases were exposed to increasing concentrations of extracellular $\mathrm{Ca}^{2+}$ (Fig. 1). The threshold concentration for the stimulatory action of $\mathrm{Ca}^{2+}$ lay between 10 and $12 \mathrm{mmol} / \mathrm{l}$. The dose-action relationship for $\mathrm{Ca}^{2+}$-induced insulin release is illustrated in the upper part of Figure 1, which refers to the integrated output of insulin over 16 minutes exposure to various $\mathrm{Ca}^{2+}$ concentrations.

\section{Pattern of $\mathrm{Ca}^{2+}$-Induced Insulin Release}

At the highest extracellular $\mathrm{Ca}^{2+}$ concentrations, the increase in insulin output was detectable within 1-2 minutes of exposure to $\mathrm{Ca}^{2+}$. However, the maximal rate of secretion was not reached until the 10th-16th minutes after the introduction of $\mathrm{Ca}^{2+}$ (Fig. 1). Such a maximal secretory rate represents at least twice that evoked by glucose $(16.7 \mathrm{mmol} / \mathrm{l})$ at close to physiological $\mathrm{Ca}^{2+}$ concentration (2 $\mathrm{mmol} / \mathrm{l})$. The progressive build-up in secretory rate during the initial period of exposure to $\mathrm{Ca}^{2+}$ was soon followed by a progressive decline in insulin output (Fig. 2). Eventually the rate of secretion returned to its basal value, which was reached after approximately 35-40 minutes of exposure to $\mathrm{Ca}^{2+}$. The fall in secretory rate during the late period does not imply a total lack of responsiveness of the pancreas, since the addition of glucose $(16.7 \mathrm{mmol} / 1)$ at the 20th minute of exposure to $\mathrm{Ca}^{2+}$ was still able to enhance the output of insulin (see inset of Figure 2).

\section{Inhibition of $\mathrm{Ca}^{2+}$-Induced Insulin Release}

When $\mathrm{Mg}^{2+}(10 \mathrm{mmol} / \mathrm{l})$ was present from the beginning of the perfusion, a complete inhibition of $\mathrm{Ca}^{2+}$-evoked insulin release was observed (Fig. 3 and Table 1). The organic $\mathrm{Ca}^{2+}$-antagonist verapamil, which inhibits $\mathrm{Ca}^{2+}$ influx in the pancreatic B-cell [6], also caused inhibition of $\mathrm{Ca}^{2+}$-induced insulin secretion at a concentration of $81 \mu \mathrm{mol} / \mathrm{l}$ (Table 1). Exposure of the pancreas to somatostatin $(1.25 \mu \mathrm{g} / \mathrm{ml})$ from time 0 to the 35 th minute significantly retarded the $\mathrm{Ca}^{2+}$-evoked insulin release (Fig. 4). From the 25th to 35 th minute of perfusion the integrated insulin output in the presence of somatostatin averaged $48 \pm 8 \%(P<0.02)$ of the mean control value found in its absence.

\section{Potentiation of $\mathrm{Ca}^{2+}$-Induced Insulin Release}

When administered together with $\mathrm{Ca}^{2+}$, glucose $(16.7 \mathrm{mmol} / \mathrm{l})$ caused a dramatic increase in the output of insulin observed at the lowest active concentration of $\mathrm{Ca}^{2+}(12 \mathrm{mmol} / \mathrm{l})$. Under these experimental conditions an apparently biphasic insulin response was observed. Glucose, at a concentration of $2.7 \mathrm{mmol} / \mathrm{l}$, failed to affect insulin release at normal 


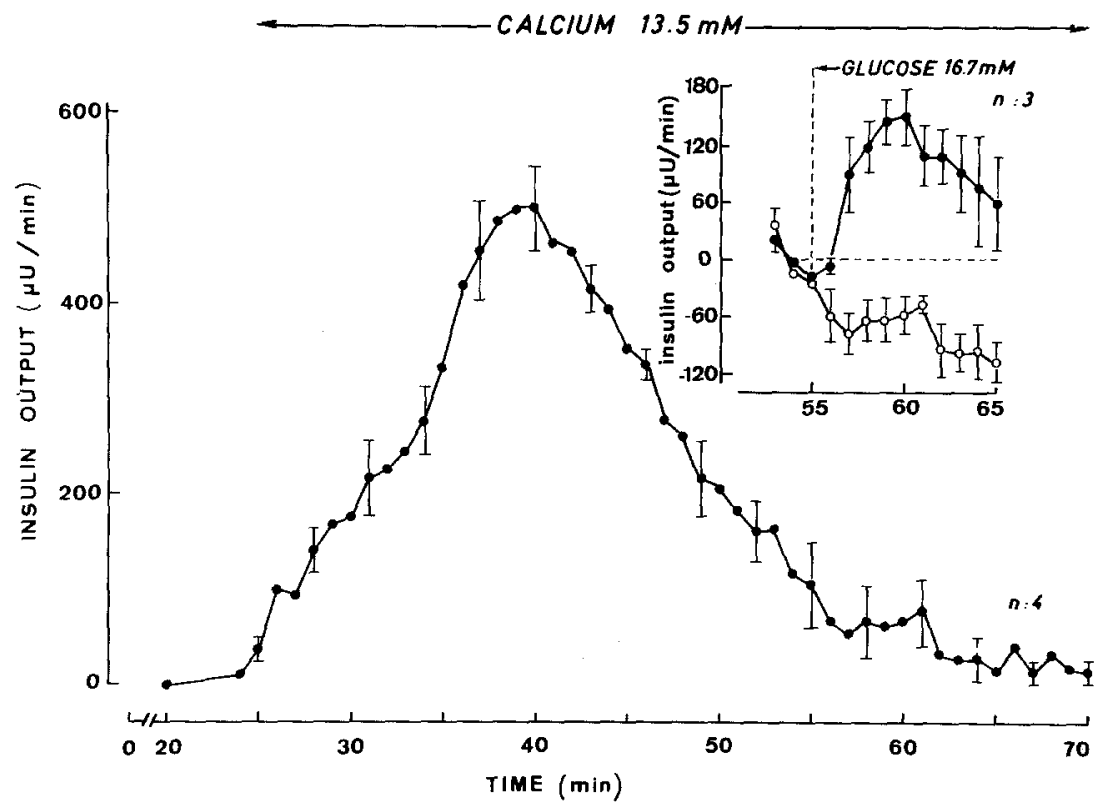

Fig. 2. Pattern of $\mathrm{Ca}^{2+}$-induced insulin release. Mean values ( \pm SEM) for insulin release evoked by $\mathrm{Ca}^{2+} 13.5 \mathrm{mmol} / \mathrm{l}$. Same presentation and experimental conditions as in Fig. 1. Inset: the open circles refer to the same experiments as those shown on the main graph; the closed circles refer to experiments in which glucose $16.7 \mathrm{mmol} / 1$ was administered from the 55 th min of perfusion onwards. The mean output seen between the $53 \mathrm{rd}$ and $55 \mathrm{th}$ min is taken as the zero reference value

Table 1. Effect of various agents upon $\mathrm{Ca}^{2+}$-induced insulin release by the isolated perfused rat pancreas ${ }^{\mathrm{a}}$

\begin{tabular}{|c|c|c|c|c|c|c|c|c|}
\hline Line & $\begin{array}{l}\mathrm{Ca}^{2+} \\
\mathrm{mmol} / 1\end{array}$ & $\begin{array}{l}\mathrm{Mg}^{2+} \\
\mathrm{mmol} / \mathrm{I}\end{array}$ & $\begin{array}{l}\text { Verapamil } \\
\mu \mathrm{mol} / 1\end{array}$ & $\begin{array}{l}\text { Glucose } \\
\mathrm{mmol} / 1\end{array}$ & $\begin{array}{l}\text { Theophylline } \\
\text { mmol/I }\end{array}$ & $\begin{array}{l}\text { Cytochalasin B } \\
\mu \mathrm{mol} / 1\end{array}$ & $\begin{array}{l}\text { Insulin output } \\
\text { (\% of control) }\end{array}$ & $P$ \\
\hline 1 & 10.0 & 1.0 & - & - & - & - & $6 \pm 2(5)$ & \\
\hline 2 & 10.0 & 1.0 & - & - & - & 21 & $16 \pm 3(5)$ & vs $1<0.05$ \\
\hline 3 & 12.0 & 1.0 & - & - & - & - & $19 \pm 3(5) \mathrm{vs}$ & vs $1<0.005$ \\
\hline 4 & 12.0 & 1.0 & - & 2.7 & - & - & $78 \pm 10(6)$ & vs $3<0.001$ \\
\hline 5 & 12.0 & 1.0 & - & 16.7 & - & - & $208 \pm 16(6)$ & vs $4<0.001$ \\
\hline 6 & 12.0 & 1.0 & - & - & 1.4 & - & $137 \pm 14(6) \mathrm{vs}$ & vs $3<0.001$ \\
\hline 7 & 12.0 & 1.0 & - & - & - & 21 & $58 \pm 3(6)$ & vs $3<0.001$ \\
\hline 8 & 13.5 & 1.0 & - & - & - & - & $62 \pm 6(10)$ & vs $3<0.001$ \\
\hline 9 & 13.5 & 1.0 & 81.0 & - & - & - & $37 \pm 4(4)$ & vs $8<0.05$ \\
\hline 10 & 18.0 & 1.0 & - & - & - & - & $100 \pm 8(7)$ & vs $8<0.002$ \\
\hline 11 & 18.0 & 1.0 & 8.1 & - & - & - & $91 \pm 15$ (4) v & vs 10 N.S. \\
\hline 12 & 18.0 & 1.0 & 81.0 & - & - & - & $57 \pm 13(4)$ & vs $10<0.02$ \\
\hline 13 & 18.0 & 10.0 & - & - & - & - & $4 \pm 1(3)$ & vs $10<0.001$ \\
\hline 14 & 18.0 & 1.0 & - & - & - & 21 & $99 \pm 1(3) v$ & vs $10 \quad$ N.S. \\
\hline
\end{tabular}

a Mean values $\left( \pm\right.$ SEM) for the integrated amount of insulin released by $\mathrm{Ca}^{2+}$ between the 25 th and 40 th min of perfusion are expressed in per cent of the mean control value shown on line 10 (i.e. $18.0 \mathrm{mmol} / \mathrm{C} \mathrm{Ca}^{2+}$ and $1.0 \mathrm{mmol} / \mathrm{l} \mathrm{Mg}{ }^{2+}$ ). Such a control value averaged $9.5 \pm 0.8 \mathrm{mU} /$ pancreas. Also shown are the number of individual experiments (in parentheses) and the statistical significance of changes in insulin output

extracellular $\mathrm{Ca}^{2+}$ concentration [5], but was capable of significantly enhancing the release of insulin evoked by $\mathrm{Ca}^{2+} 12 \mathrm{mmol} / \mathrm{l}$ (Fig. 5 and Table 1 ). Theophylline $(1.4 \mathrm{mmol} / \mathrm{l})$ also markedly enhanced the secretion of insulin evoked by $\mathrm{Ca}^{2+} 12 \mathrm{mmol} / 1$ (Table 1). The mould metabolite cytochalasin B (21 $\mu \mathrm{mol} / \mathrm{l})$ potentiated insulin release induced by $\mathrm{Ca}^{2+}$ $12 \mathrm{mmol} / 1$ (Fig. 6), but failed to affect significantly the higher rate of secretion evoked by $\mathrm{Ca}^{2+} 18$ $\mathrm{mmol} / 1$ (Table 1). Cytochalasin B apparently lowered the threshold value for the stimulatory action of $\mathrm{Ca}^{2+}$ on insulin release. Indeed, in the presence of cytochalasin $\mathrm{B}$, a $\mathrm{Ca}^{2+}$ concentration of $10 \mathrm{mmol} / \mathrm{l}$ was sufficient to increase insulin output significantly. The total amount of insulin released over the 16 minute period of exposure to $\mathrm{Ca}^{2+} 10 \mathrm{mmol} / 1$ averaged $560 \pm 164 \mu \mathrm{U}(\mathrm{n}=5)$ and $1474 \pm 320 \mu \mathrm{U}(\mathrm{n}$ $=5)$ in the absence and presence of cytochalasin $B$, respectively.

\section{Discussion}

We have recently shown that, in the absence of any other secretagogue, $\mathrm{Ca}^{2+}$ is able to provoke a shortlived insulin response in the perfused rat pancreas 


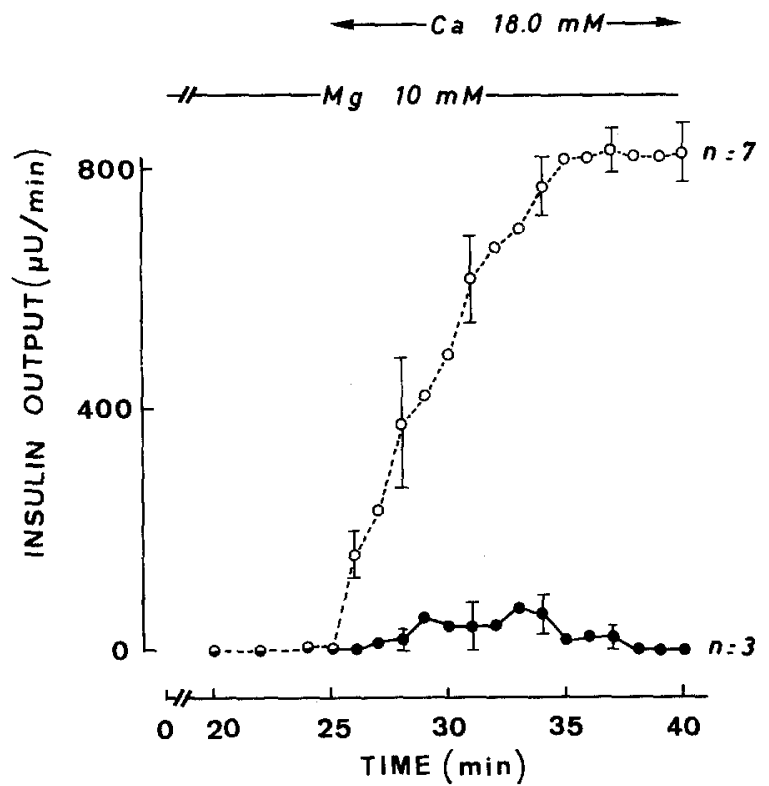

Fig. 3. Effect of $\mathrm{Mg}^{2+}$ on $\mathrm{Ca}^{2+}$-induced insulin release. The control experiments in which $\mathrm{Ca}^{2+} 18 \mathrm{mmol} / \mathrm{l}$ was introduced at the 25 th min of perfusion are shown by the open circles. Same presentation and experimental conditions as in Fig. 1. The data obtained in the presence of $\mathrm{Mg}^{2+}(10 \mathrm{mmol} / \mathrm{l})$ are given by the closed circles

$$
\text { drnoCa } \longrightarrow \text { Ca12.0mM,glu }\left\{\begin{array}{l}
16.7 \mathrm{mM} \\
2.7 \mathrm{mM}- \\
0.0 \mathrm{mM}
\end{array}\right.
$$

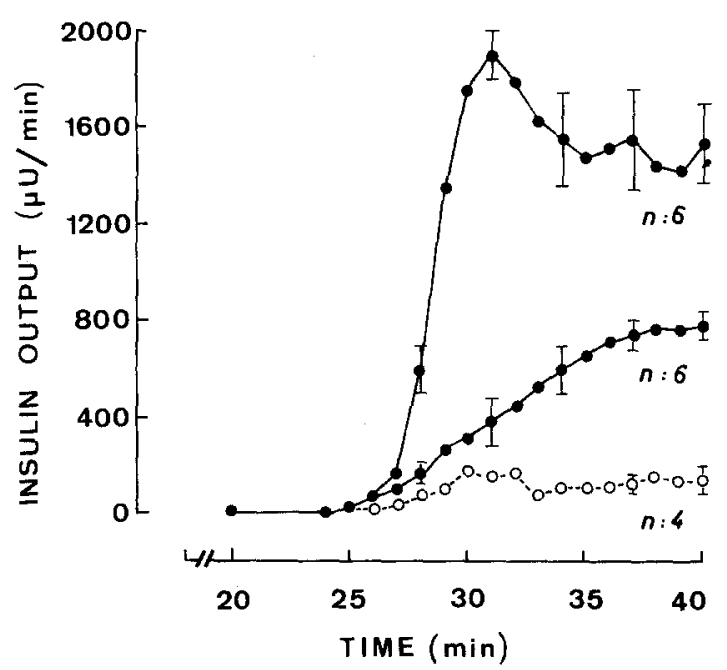

Fig. 5. Effect of glucose upon $\mathrm{Ca}^{2+}$-induced insulin release. The control experiments in which $\mathrm{Ca}^{2+} 12 \mathrm{mmol} / \mathrm{l}$ was introduced at the 25th min of perfusion are shown by the open circles. Same presentation and experimental conditions as in Fig. 1. The data obtained when glucose was introduced together with $\mathrm{Ca}^{2+}$ are shown by the closed circles (glucose $2.7 \mathrm{mmol} / \mathrm{l}$ : middle curve; glucose $16.7 \mathrm{mmol} / 1$ : upper curve)

first exposed to the $\mathrm{Ca}^{2+}$-chelating agent (EGTA [3]. Hellman, using a Hepes-buffered medium, was able to provide even more direct evidence for the stimulatory role of $\mathrm{Ca}^{2+}$, showing that under suitable experimental conditions pretreatment with

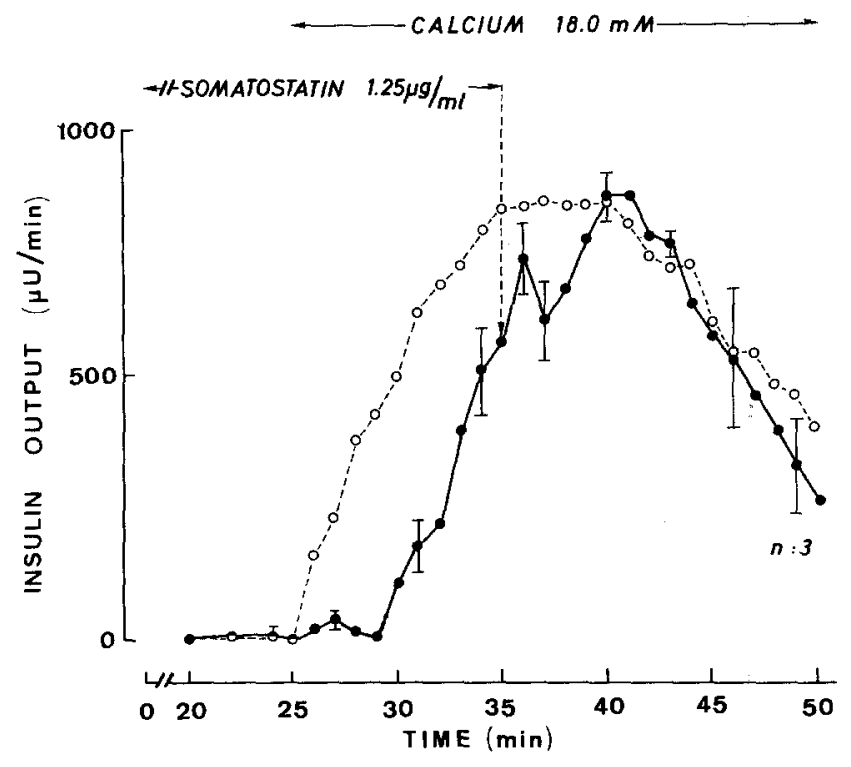

Fig. 4. Effect of somatostatin on $\mathrm{Ca}^{2+}$-induced insulin release. The control experiments in which $\mathrm{Ca}^{2+} 18 \mathrm{mmol} / \mathrm{l}$ was introduced at the 25 th $\min$ of perfusion are shown by the open circles. Same presentation and experimental conditions as in Fig. 1. The data obtained when somatostatin $(1.25 \mu \mathrm{g} / \mathrm{ml})$ was present from time zero until the 35 th $\mathrm{min}$ are shown by the closed circles

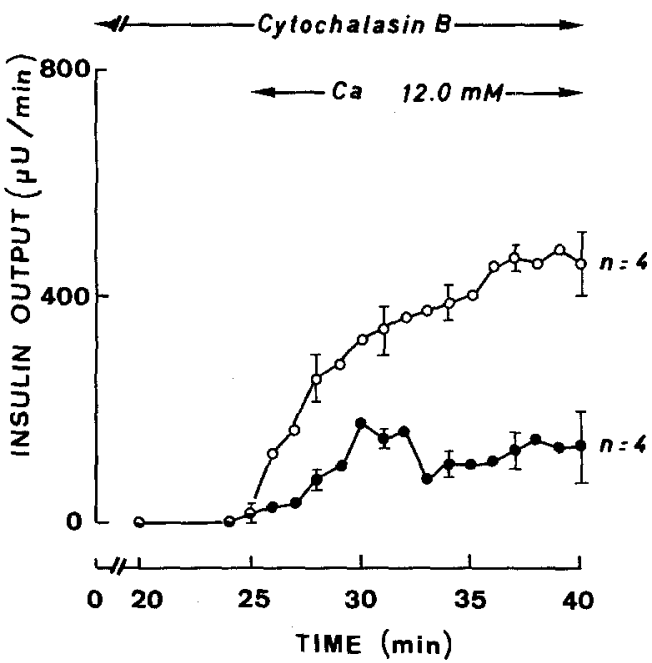

Fig. 6. Effect of cytochalasin $\mathrm{B}$ on $\mathrm{Ca}^{2+}$-induced insulin release. The control experiments in which $\mathrm{Ca}^{2+} 12 \mathrm{mmol} / \mathrm{l}$ was introduced at the 25th min of perfusion are shown by the closed circles. Same presentation and experimental conditions as in Fig. 1 . The data obtained in the presence of cytochalasin B $(21 \mu \mathrm{mol} / \mathrm{l})$ are shown by the open circles

a $\mathrm{Ca}^{2+}$-deficient medium is not a pre-requisite for the divalent cation to induce insulin release [4]. The data presented in this report confirm that extracellular $\mathrm{Ca}^{2+}$ concentrations, above a threshold value of $10 \mathrm{mmol} / 1$, provoke a dose-dependent stimula- 
tion of insulin secretion. In contrast with the brief spike of insulin release obtained after pretreatment with EGTA [3], a progressive build-up and monophasic insulin response was observed.

The reason why a sustained secretion of insulin failed to occur is not evident. It could be due to an untoward metabolic effect, since after prolonged exposure $\left(90 \mathrm{~min}\right.$ ) to a high $\mathrm{Ca}^{2+}$ concentration (20 $\mathrm{mmol} / \mathrm{l})$, glucose fails to exert its usual stimulant action on ${ }^{45} \mathrm{Ca}^{2+}$ net uptake by isolated islets (unpublished observations). The assumption that an increase in the size of the functionally active pool(s) of $\mathrm{Ca}^{2+}$ above a certain optimal value could induce per se a diminished insulin secretory response seems untenable [8]. Indeed, glucose, which is known to cause an increase in the total net uptake of $\mathrm{Ca}^{2+}$ by the B-cell, remained capable of enhancing insulin output at the very time during perfusion when the hormonal release was falling towards its basal level.

The insulinotrophic effect of $\mathrm{Ca}^{2+}$ could be due to the fact that high extracellular $\mathrm{Ca}^{2+}$ concentrations favour the cytosolic accumulation of this cation, ultimately triggering the secretory response. Unpublished observations have shown that, over 90 minutes incubation in the absence of glucose, the net uptake of ${ }^{45} \mathrm{Ca}^{2+}$ by isolated islets dramatically increases, from $1.34 \pm 0.10$ to $9.52 \pm 0.74 \mathrm{pmol} /$ islet ( $\mathrm{n}=13$ in each case), as the $\mathrm{Ca}^{2+}$ concentration of the Hepes-buffered incubation medium is raised from 5 to $20 \mathrm{mmol} / \mathrm{l}$.

It is likely that, in the process of $\mathrm{Ca}^{2+}$-induced insulin release, the rate of $\mathrm{Ca}^{2+}$ entry in the $\mathrm{B}$-cell plays a critical role. The latter hypothesis is supported by the finding that $\mathrm{Ca}^{2+}$-induced insulin release is inhibited at high extracellular $\mathrm{Mg}^{2+}$ concentrations. We have previously shown that $\mathrm{Mg}^{2+}$ is a potent inhibitor of $\mathrm{Ca}^{2+}$ entry in the B-cell [9], probably by competing with $\mathrm{Ca}^{2+}$ for a common cationic carrier-system located within the B-cell plasma membrane. The same competitive effect of $\mathrm{Mg}^{2+}$ is observed in the case of $\mathrm{Ba}^{2+}$ uptake by the $\mathrm{B}$-cell [10]. The organic $\mathrm{Ca}^{2+}$-antagonist verapamil also inhibits $\mathrm{Ca}^{2+}$-induced insulin release. It is thus plausible that under the present experimental conditions, $\mathrm{Ca}^{2+}$ enters the B-cell at the intervention of a native ionophoretic system which, like the exogenous ionophore A23187, would act by virtue of its verapamilsensitive $\mathrm{Ca}^{2+}$-binding sites [7]. We have indeed recently observed that verapamil inhibits the capacity of the ionophore $\mathrm{A} 23187$ to provoke $\mathrm{Ca}^{2+}$ translocation in an artificial model [11]. Verapamil could also interfere with the $\mathrm{Ca}^{2+}$-binding sites of the native ionophoretic systems located in the B-cell plasma membrane and, by doing so, inhibit the entry of $\mathrm{Ca}^{2+}$ in the B-cell.
It has been proposed by various investigators that the effects of somatostatin on hormonal discharge are related to an alteration in the handling of or response to $\mathrm{Ca}^{2+}[12-14]$. This hypothesis is compatible with the wide-spread inhibitory action of somatostatin on hormone release [15-21] and the role of $\mathrm{Ca}^{2+}$ as a cellular messenger in various secretory cells [22]. The data here obtained with somatostatin are also in good agreement with such a hypothesis. Exposure of the pancreas to somatostatin did significantly retard the secretory response to $\mathrm{Ca}^{2+}$. It was recently shown that somatostatin $(2 \mu \mathrm{g} / \mathrm{ml})$ significantly decreases glucose-induced ${ }^{45} \mathrm{Ca}^{2+}$-uptake by isolated islets [14].

The potentiating effect of glucose upon $\mathrm{Ca}^{2+}$-induced insulin release is consistent with the fact that this hexose increases the net uptake of $\mathrm{Ca}^{2+}$ by the B-cell. Our finding that a $2.7 \mathrm{mmol} / 1$ concentration of glucose was sufficient to enhance $\mathrm{Ca}^{2+}$-induced insulin release would suggest that this sugar is able to affect $\mathrm{Ca}^{2+}$-handling even when used at a concentration far below that normally required to stimulate insulin release. This is not surprising since the rate of glycolysis, which exerts a tight control upon $\mathrm{Ca}^{2+}$ net uptake by the B-cell [23], is indeed higher in the presence of glucose $2.7 \mathrm{mmol} / 1$ than in the absence of glucose. Moreover, the efflux of ${ }^{45} \mathrm{Ca}^{2+}$ from perifused islets is slightly but significantly reduced by glucose in a concentration ( 2.5 $\mathrm{mmol} / \mathrm{l}$ ) lower than that required to stimulate insulin release at a physiological concentration of extracellular $\mathrm{Ca}^{2+}$ [24].

Theophylline also enhanced $\mathrm{Ca}^{2+}$-evoked insulin release, a finding which is in good agreement with the data obtained by Hellman with isobutylmethylxanthine [4]. These phosphodiesterase inhibitors augment the cyclic-AMP content of the B-cell [8, 25] and, by doing so, may cause a redistribution of $\mathrm{Ca}^{2+}$ ions within the B-cell [26]. Since cyclic-AMP is known to inhibit the net uptake of $\mathrm{Ca}^{2+}$ by $\mathrm{B}$-cell subcellular particulate fractions [27], our findings suggest that the ability of mitochondria and/or other organelles to store divalent cations plays an important counter-regulatory role in modulating the magnitude of the secretory responses to either $\mathrm{Ca}^{2+}$ or $\mathrm{Ba}^{2+}[10]$.

Taken as a whole, the present data are compatible with the idea that a rise in the extracellular $\mathrm{Ca}^{2+}$ concentration, by increasing $\mathrm{Ca}^{2+}$ entry and/or inhibiting $\mathrm{Ca}^{2+}$ efflux, provokes a sufficient accumulation of $\mathrm{Ca}^{2+}$ in the B-cell to stimulate insulin release. It has been proposed that the cytosolic accumulation of $\mathrm{Ca}^{2+}$ triggers insulin secretion by activating a microtubular-microfilamentous effectorsystem responsible for the exocytosis of secretory 
granules. Our findings with cytochalasin B reinforce this concept, since $\mathrm{Ca}^{2+}$-induced insulin release is itself enhanced by this metabolite. As already reported in the case of glucose- or leucine-induced insulin secretion $[5,28]$, cytochalasin B not only potentiates the secretory response to the secretagogues but also lowers the threshold concentration at which insulinotropic agents become able to evoke insulin release. The mould metabolite may thus sensitize the response of the effector system to sub-threshold concentrations of cytosolic $\mathrm{Ca}^{2+}$ [29].

Acknowledgements. The authors wish to thank Miss G. De Pauw, Mrs. J. Schoonheydt and Mr. G. Schoonjans for technical assistance, and Mrs. B. Noël for secretarial help. This work was supported by grants $20.353,3.4527 .75$ and 3.4537 .76 from the Belgian Foundation for Medical Research and a contract of the Belgian Ministry of Scientific Policy within the framework of the association Euratom - Universities of Brussels and Pisa

\section{References}

1. Malaisse, W.J., Herchuelz, A., Levy, J., Somers, G., Devis, G., Ravazzola, M., Malaisse-Lagae, F., Orci, L.: Insulin release and the movements of calcium in pancreatic islets. In: E. Carafoli, F. Clementi, W. Drabikowski, A. Margreth (Eds.): Calcium Transport in Contraction and Secretion, pp. 211-226. Amsterdam: North-Holland Publishing Company 1975

2. Malaisse, W.J.: Insulin secretion: multifactorial regulation for a single process of release. Diabetologia 9, 167-173 (1973)

3. Devis, G., Somers, G., Malaisse, W.J.: Stimulation of insulin release by calcium. Biochem. Biophys. Res. Commun. 67, 525-529 (1975)

4. Hellman, B.: Stimulation of insulin release after raising extracellular calcium. FEBS Lett. 63, 125-128 (1976)

5. Van Obberghen, E., Somers, G., Devis, G., Vaughan, G. D., Malaisse-Lagae, F., Orci, L., Malaisse, W. J.: Dynamics of insulin release and microtubular-microfilamentous system. I. Effect of cytochalasin B. J. Clin. Invest. 52, 1041-1051 (1973)

6. Levy, J., Herchuelz, A., Sener, A., Malaisse, W. J.: Inhibition by verapamil of calcium influx in the B-cell. Diabetes 24, 400 (1975)

7. Somers, G., Devis, G., Malaisse, W. J.: Analogy between native and exogenous ionophores in the pancreatic B-cell. FEBS Lett. 66, 20-22 (1976)

8. Hellman, B.: The significance of calcium for glucose stimulation of insulin release. Endocrinology 97, 392-398 (1975)

9. Malaisse, W. J., Devis, G., Herchuelz, A., Sener, A., Somers, G.: Calcium antagonists and islet function. VIII. The effect of magnesium. Diab. Métab. (Paris) 2, 1-4 (1976)

10. Somers, G., Devis, G., Van Obberghen, E., Malaisse, W.J.: Calcium-antagonists and islet function. VI. Effect of barium. Pflügers Arch. 365, 21-28 (1976)

11. Malaisse, W.J., Devis, G., Somers, G.: Inhibition by verapamil of ionophore-mediated calcium translocation. Experientia (in press) (1977)

12. Curry, D. L., Bennett, L. L.: Reversal of somatostatin inhibition of insulin secretion by calcium. Biochem. Biophys. Res. Commun. 60, 1015-1019 (1974)

13. Fujimoto, W.Y., Ensinck, J.W.: Somatostatin inhibition of insulin and glucagon secretion in rat islet culture: reversal by ionophore A 23187. Endocrinology 98, 259-262 (1976)

14. Bhatena, S. J., Perrino, P. V., Voyles, N. R., Smith, S.S., Wilkins, S. D., Coy, D. H., Schally, A. V., Recant, L.: Reversal of somatostatin inhibition of insulin and glucagon secretion. Diabetes 25, 1031-1040 (1976)

15. Brazeau, P., Vale, W., Burgus, R., Ling, N., Burcher, M., River, J., Guillemin, R.: Hypothalamic polypeptide that inhibits the secretion of immunoreactive pituitary growth hormone. Science 179, 77-79 (1973)

16. Weeke, J., Prange-Hansen, A., Lundbaek, K.: The inhibition by somatostatin of the thyrotropin response to thyrotropinreleasing hormone in normal subjects. Scand. J. Clin. Lab. Invest. 33, 101-103 (1974)

17. Tyrrell, J. B., Lorenzi, M., Gerich, J. E., Forsham, P. H.: Inhibition by somatostatin of ACTH secretion in Nelson's syndrome. J. Clin. Endocrinol. Metab. 40, 1125-1127 (1975)

18. Bloom, S.R., Mortimer, C.M., Thorner, M.O., Besser, G.M., Hall, R., Gomez-Pau, A., Roy, V.M., Russel, R.C.G., Coy, D.H., Kastin, H.J., Schally, A. V.: Inhibition of gastrin and gastric acid secretion by growth hormone release-inhibiting hormone. Lancet 1974 II, 1106-1109

19. Gerich, J. E., Lovinger, R., Grodsky, G. M.: Inhibition by somatostatin of glucagon and insulin release from the perfused rat pancreas in response to arginine, isoproterenol and theophylline: evidence for a preferential effect on glucagon secretion. Endocrinology 96, 749-754 (1975)

20. Johnson, D. G., Ensinck, J.W., Koerker, D., Palmer, J., Goodner, C. J.: Inhibition of glucagon and insulin secretion by somatostatin in the rat pancreas perfused in situ. Endocrinology 96, 370-374 (1975)

21. Curry, D. L., Bennett, L. L., Li, C. H.: Direct inhibition of insulin secretion by synthetic somatostatin. Biochem. Biophys. Res. Commun. 38, 885-887 (1974)

22. Rasmussen, H.: Cell communication, calcium ion, and cyclic adenosine monophosphate. Science 170, 404-412 (1970)

23. Sener, A., Levy, J., Malaisse, W. J.: The stimulus-secretion coupling of glucose-induced insulin release. Does glycolysis control calcium transport in the B-cell? Biochem. J. 156, 521-525 (1976)

24. Herchuelz, A., Mahy, M.: Influence of sub-threshold glucose concentrations and theophylline on the rapidity of glucose-induced calcium accumulation and exocytotic release in perifused islets. Diabetologia 10, 369 (1974)

25. Charles, M. A., Lanecki, J., Pictet, R., Grodsky, G. M.: Insulin secretion. Interrelationships of glucose, cyclic adenosine $3^{\prime}: 5^{\prime}$-monophosphate, and calcium. J. Biol. Chem. 250, 6134-6140 (1975)

26. Malaisse, W. J.: Effects of cyclic AMP on B-cell function. In: J.E. Dumont, B.L. Brown, N. J. Marshall (Eds.): Eukaryotic Cell Function and Growth, pp. 633-638. New York: Plenum Publishing Corporation 1976

27. Howell, S.L., Montague, W., Tyhurst, M.: Calcium distribution in islets of Langerhans: a study of calcium concentrations and of calcium accumulation in B-cell organelles. J. Cell. Sci. 19, 395-409 (1975)

28. Levy, J., Herchuelz, A., Sener, A., Malaisse-Lagae, F., Malaisse, W. J.: Cytochalasin B-induced impairment of glucose metabolism in islets of Langerhans. Endocrinology 98, 429-437 (1976)

29. Malaisse, W.J., Pipeleers, D. G., Van Obberghen, E., Somers, G., Devis, G., Marichal, M., Malaisse-Lagae, F.: The glucoreceptor mechanism in the pancreatic beta-cell. Am. Zool. $13,605-612$ (1973)

Received: February 21, 1977, and in revised form: May 17, 1977

Dr. W. J. Malaisse

Laboratoire de Médecine Experimentale

Boulevard de Waterloo 115

B-1000 Brussels

Belgium 